\title{
ВЕЉКО ПЕТРОВИЋ И ИВО МУНЋАН: ЈЕДАН ПОЕТИЧКИ УКРШТАЈ
}

Предмет рада је компаративна анализа поетика писаца равничара, Иве Мунћана и Вељка Петровића, са нарочитим освртом на следећа дела: родољубиве и социјалне песме Вељка Петровића, приповетке Буња, Салашар, Земља, Бели Деда, Карловачки доживљај 1889. године овог писца, као и на збирку прича У вртлогу времена и романе Бесана ноћ и Сунце на кришке Иве Мунћана. У наведеном корпусу истражујемо теме и мотиве преплитања две поетике усмерене ка проблему националног идентитета и идентитета појединца у контакту са модерним временом. Нарочита пажња посвећена је проналажењу сличности у развијању и значењу мотива земље, села и традиције, у обликовању јунака и у приповедном поступку Вељка Петровића и Иве Мунћана.

Кључне речи: Иво Мунћан, Вељко Петровић, антејски мотиви, идентитет, традиција, усмено приповедање.

Он је реч земье. [...] Обећао је земьи да ће се његово биће у њој обескрајити. Исидора Секулић, 1924

„Глава и дух би још нешто да напишу, али рука не може, издала ме је, проклета. Остаје ми да се надам да ће, сем оних који су ме волели, бити међу младима и таквих који ће читати моје, и не само моје књиге." (Поповић, 2009: 237) - изговорио Вељко Петровић тог 27. јула 1967. године, гласом који тек да је реметио тишину. Али тај глас није утишан првим прегрштом земље која је истог дана пала на ковчег Вељка Петровића у Алеји народних хероја. Из расклопљене књиге полетела је „Вељкова голубица”, данас престижна књижевна награда чији су лауреати писци који стварају у духу поетике Вељка Петровића. ${ }^{4}$ Том низу писаца лауреата инспирисаних поетиком Вељка Петровића свакако се може додати Иво Мунћан, писац рођен

\footnotetext{
${ }^{1}$ mirjana.bojanic.cirkovic@filfak.ni.ac.rs

${ }^{2}$ Рад је настао у оквиру пројекта Истраживање културе и историје Срба у Румунији Центра за научна истраживања културе Срба у Румунији.

${ }^{3}$ Ову књижевну награду додељује Град Сомбор за свеукупно приповедачко стваралаштво на српском језику.

${ }^{4}$ Први лауреат књижевне награде „Вељкова голубица”је Мирослав Јосић Вишњић (2007).
} 
у Тимишкој жупанији и аутор збирки песама Жетеоци дуге (1978), Исходимте (1996), Љубичасто небо (2003), монографије Била једном слога једна (2013), антологије Откривање Срба (2012), дела У походе коренима: белешке за преглед старе српске књижевности (2001) и низа других текстова који тематско-мотивски, избором ликова и садржајем кореспондирају са поетиком Вељка Петровића.

Тему поетичког укрштаја дела Иве Мунћана са Петровићевим назначили смо у раду „Антејски мотиви збирке прича $У$ вртлогу времена Иве Мунћана”: „Именом овог античког дива [Антеја, прим. аут.] Скерлић је назвао једино песника и прозаисту Вељка Петровића. С друге стране, сам Вељко Петровић је насловом једне од својих родољубивих песама изузетне лепоте наслутио долазак 'нових Антеја' који ће наставити линију стиховног и прозног тематизовања земље као култа сигурности и постојаности и човека који се једино са њеног тла може дићи 'оснажен и силан, / ко некад Титан' (Петровић, 1969: 57). Земља, равница, човек, природа, тежачки рад као најфреквентнији мотиви Петровићевих дела, неретко истицани самим насловима (уп. Човечја земља, Кад сељак умире, Похвала равници, Земаљски звуци, У жетвене дане), средишњи су мотиви већине прозних дела Иве Мунћана. У више наврата књижевни критичари су истакли да је Иво Мунћан својим делима успео да дочара равничарско банатско поднебље (Поповић, 1973; Милин, 1977), човекову емоционалну повезаност са широком равницом (Вукадиновић, 1992), али и унутрашње тензије човека укорењеног у њу (Клисурац, 1973).” (Бојанић Ћирковић, 2018: 49-50)

Циљ овог рада је указати на још поетичких укрштаја двојице равничарских писаца сем назначених тематско-мотивских прожимања и истаћи њихове стилске, композиционе и приповедачке сродности.

\section{2. Усмењаци}

О лепом говорном језику Вељко Петровић није само писао у истоименом огледу, већ је, како истичу поједини тумачи Петровићевих дела (Глигорић, 1955; Гордић, 2000. и др.), њиме писао своје књижевноуметничке текстове. Пишући о приповедачком опусу Вељка Петровића, Јован Деретић (1987: 118) истиче да се у „начину приповедања осећа усмереност на живу, изговорену реч" и указује на заступљеност приповедања у првом лицу у Петровићевој прози. Велибор Глигорић (1955) је истакао да Петровић као приповедач ,своју опсервацију предаје непосредно, срдачно и директно заинтересованом читаоцу”; Гордић (2000) га је назвао усмењаком „чија се живописна опажања и вртоглаве досетке памте и препричавају”. Мирослав Крлежа је такође истицао жив и сугестиван језик Петровићевих дела. И приповедачи Мунћанових дела (равничари, повратници, домаћини, паори, ста- 
рине) приповедају своју животну причи, „кратку и обичну” (Мунћан, 2013: 57) Њихова перманентна потреба за саговорником и „шачицом разговора” открива снажну жељу усамљеног човека у опустелим равничарским селима за блискошћу. Тренуци разговора за њих су бокори радовања; зато је њихова прича без ламента, а пуна дигресија које светкују реч, глас и звук као потврду живота. Збирка $У$ вртлогу времена је колаж таквих прича из живота које светкују радост причања, односно задовољство у причању. Свака глава романа Сунце на кришке једна је од мноштва прича које је приповедач желео да (нам) остави у аманет. ${ }^{5}$

Јунак прозе Вељка Петровића је „без изузетка дошао из мање вароши, из паланке, са села, из неког засеока; горштак, равничар" и сваки уноси у град своје носталгије, наречја; а сви они деле исти укус, исти доживљај ритма и шума града. ${ }^{6}$ Прозни текстови Иве Мунћана бременити су монолошким исказима, самопосматрањима, интроспекцијама и аутобиографским елементима јер се банатска равница тимишке жупаније често јавља као место радње дела овог писца. Јунак Мунћанове збирке стрепи од свог или туђег одласка. На своме/са свог тла бори се да се „опанци врате у бразде”.

Усмењаци Вељко Петровић и Иво Мунћан разликују се по форми у коју су заоденули причу о својим равничарима. Прозни текстови Мунћанове збирке $У$ вртлогу времена жанровски су блиски „причи из живота” о којој је писао Душан Иванић (2015: 5) у истоименом тексту наводећи да је то кратки, самостални прозни облик где се извесне животне (документарне) чињенице саопштавају као целовите, сижејно уобличене приповетке/приче. Поједине Мунћанове приче из живота имају слободнији однос према својим жанровским границама; примера ради, прича „Старац и сунце” блиска је новинској репортажи, а њена документарна страна ојачана је транскриптом ,записа са траке” насталом у кући једног банатског старине. Вељко Петровић се определио за форму српске реалистичке приповетке, али без поджанроцских одредница слике и др. И у погледу обликовања јунака углавном је био реалист: поступке својих јунака објашњавао је спољашњим, социјалним чиниоцима, али запостављао ни њихове карактерне црте и темперамент. Оцењујући Петровићев укупан приповедачки рад који садржи око две стотине приповедака, Јован Деретић (1987: 117) закључује да је Петровић ,тематски проширио и обогатио српску приповетку, ослободио је њених ранијих ограничености; код њега нема регионализма, фолклоризма ни социјалне периферије у приступу, све о чему пише уноси погледе модерног човека који никада није изгубио везу с народом.” Ове усмењаке, писце реалистичке приповетке и кратке приче, надасве повезује утисак истинитог, реалног и живог у њиховим делима.

\footnotetext{
5 УП. „Ето, то сам још хтео да вам кажем.“ (91)

${ }^{6}$ Парафраза речи Вељка Петровића у часопису Југославија; нав. према: Поповић, 2009: 170.
} 


\section{3. Писци узмућених душевних стања}

Бити до краја и недељиво изео. Буња, Вељко Петровић

Давне 1908. године, Јован Скерлић је Вељка Петровића, тада младог ствараоца чије име тек почиње бивати познато, назвао „најбољим живим песником старе Војводине” истичући да ће име „обновитеља патриотске поезије" заузети значајно место у српској књижевности. Попут Вељак Петровића чији књижевни живот почиње избором из књиге песама На прагу, публикованом у Летопису Матице српске 1908. године, а наставља се збирком Родољубиве песме (1912), Иво Мунћан у књижевност такође улази као песник лирске исповести (збирке Видици маште, 1966. и Исповести, 1971) и у даљем стваралаштву, без обзира на промену жанровског лика, попут Вељка Петровића остаје песник равнице. Нису ретка запажања књижевних критичара о приповеткама Раванграда као слици и песми Војводине и њених „ урбанизираних личности које као чардаци између неба и земље, распете лебде у неком вакууму времена које као да је стало и простора који као да је поремећен и испретуран, док се у њему пропињу и затежу амбиције, страсти, нагони и жудње, стапајући се у широку панораму једног света разливеног по непрегледу монотоне равнице и оболелог од чудног панонског бола.” (Палавестра, 1963) Без обзира на жанровски лик овог „разумевања човека”, Вељко Петровић је, како је сам о себи рекао, „Поета! Увек! Увек!” (Поповић, 2009: 171). У прозном опусу Иве Мунћана готово да нема приповетке у којој се не прожимају прозно и поетско; један од разлога свакако је тај што се Мунћан, као и Вељко Петровић, подједнако успешно остваривао као песник и прозаиста. Примера ради, поједини сегменти збирке прича $У$ вртлогу времена И. Мунћана налик су песмама у прози, а као науспелије можемо издвојити дело „Старац и сунце”, лирску исповест старине која путем песничке слике бујице боја и игре зрака Сунца дочарава тренутке старинине радости због ретког присуства саговорника у тихој равници и његову стрепњу да сваког трена поново може остати сам. Међутим, усамљеност као типична црта Мунћанових и Петровићевих јунака у делима ових писаца рачва се ка помирљивости и тихој патњи и ка гласном исповедном монологу бунта и горком плачу, као у „повести човека без корена”, Буњи. Али, приповетке двојице писаца са ликом равничара остају повезане поступком градације јер у њима туга кулминира: и Мунћанов старина и Стипа Паштровић заплачу и јаукну тихо, односно громко. И у једном и у другом контексту, усамљеност је мотивисана „лудошћу чекања и трпљења” (Петровић, 1968: 103).

Мотив усамљености у опусу двојице писаца по правилу се развија унутар теме идентитета (националног и личног) и укорењености. Кулми- 
нативна фаза Буњине исповести на најбољи начин осветљава терет душе располућене између онога што собом носи и наноса туђих адета и амбиција: „Ја сам лебдео, венуо без корена. Јер ја сам Буња, прави правцати салашар Буња, који је понео топло срце, напупело крај земљаног белог банка, у свет ваш, где је прва врлина ишчупати срце што раније, још неразвијено и зелено, или га притајити.” (Петровић, 1968: 111) И јунак Мунћановог дела (нарочито романа Бесана ноћ, Сунце на кришке и приповедака збирке У вртлогу времена) је једноставан у свом погледу на свет, носилац здравог, народског поштења и части, епски несебичан, али вечити несмирник кога напаја (и у исти мах чини горљивим) силно родољубиво осећање. Мунћанов и Петровићев јунак горљиви су у жељи да се укорене на своме и да управо та њихова снага буде светлост (путоказ) у мраку будућности који наслућују.

Прозу Вељка Петровића и Иве Мунћана повезује панорамска ширина сликања друштвеног и географског простора у којем се нијансира психолошка димензија јунака (било индивидуалног, било колективног). Двојица приповедача и песника унизала су своја дела у ,заједнички” циклус „из нашег живота”, из „доброћудних равница” које изнедре „доброћудног” појединца који сваким кораком од равнице, а ка нервозном, мемљивом свету допадне трагичних душевних криза. Да Вељко Петровић радо слика „узмућена душевна стања" (Поповић, 2009: 47), истакао је готово сваки књижевни критичар и историчар књижевности који је писао о делу Вељка Петровића. Оно што се још може ишчитати између редова критике, а понајвише из Петровићевих дела, јесте једна нијанса - Петровићево „сликање” ређих осећања. И ,равница је само привидно једнолика и привидно ћутљива”, записао је Вељко Петровић у Похвали равници. У приповеци Земља, у пролеће 1918, у лику Сремца Саве Недељковића Петровић осветљава „оно што је врило, што је подмукло локало“ у душама човека; једно ,трагично мрачно раположење” које је у њему лежало као „оловни талог”. Главни мотив ове приповетке, воз, израста у симбол човекове душе: у возу се дахће, зноји, брише и свлачи до кошуље; и души је тесно у тим „чудним нашим путовањима”, под оловним талогом прошлости („Сувише се дуго робовало.”, Карловачки доживљај 1889, стр. 38). Воз који, увек у покрету и протоку, напослетку остаје празан, метафора је празне душе Саве Недељковића у тренуцима ишчекивања вести о свом сину Милошу, матуранту Карловачке гимназије и стрепње да ће остати без крста и људског гроба. Оловни талог нагриза (уп. „Такви смо и ми сви, Срби, много је киселине у нама, зависти, злурадости, неумерености и нестрпљиве амбиције и таштине.", Карловачки доживљај 1889.) Вељкови приповедачи и Вељков лирски субјекат опажају „оно невидљиво друштвено врење и сазревање чему нешто слично налазимо у природи, у глувим и плодним летњим ноћима, када, што се вели, трава расте, пупољци пуцају а зрна бубре...” (Вељко Петровић о својој прози, нав. према: Поповић, 2009: 195) „Равница у до сада узетом смислу је симбол плодности, извориште живота у свој његовој разноликости.”, истиче 
и Тихомир Петровић (2014: 13) у огледу о равници у делу приповедача о којем говоримо.

Банатски равничарски хронотоп место је укрштаја послератног времена, судбине ликова и подлога је друштвених, економских и политичких превирања у роману Сунце на кришке Иве Мунћана. У контексту поетике сликања душевних стања јунака, упечатљива је сцена путовања на лађи у Мунћановој причи Старац и Суниее (У вртлогу времена). Бљесак зеленог Сунца, са дугачким пипцима на палуби лађе, пробудио је печалбареву стрепњу. Кроз зелени облак смењивале су се слике сивог, „чужег” сокака и разнетог покућства. Доживљај зеленог сунца посредно говори о старининим стрепњама за сина који је отишао из равнице. Зелено сунце је сунце патње; оно „цијуче, урличе”. Међутим, и под „чопором облака” старина и даље жуди за својом „кришком Сунца”. Значајан корпус Мунћанових приповедака може се означити ехом Петровићеве „повести човека без корена” или Буњине исповести. „Наш човек”, др Стипа Паштровић, адвокат, човек утихлих хтења, неостварених жеља, „тућ” човек „конзервативног буњевачког срца" који чезне за топлином салаша багремима осенченог, биланс промашеног живота своди и у Мунћановој прози: микро-роман Бесана ноћ је, заправо, бесано саслушавање савести, своје и туђе. „Белешке” романа су фрагментарног карактера, без датирања, чиме се подцртава средишња тема дела, сукоб свести и савести. Међутим, у Мунћановим (микро)романима ова „борба” се потире на попришту доживљаја равнице; док се јунак перманентно преиспитује у вези са одлукама које је донео, а које се тичу одлазака и растава, приповедна и доживљајна перспектива стапају се у тренутку помена мотива земље, сунца и равничарског неба. То је „Света тројица” јунаковог детињства и његовог бића.

\section{4. Песници родне груде}

Књижевнокритички текстови о стваралаштву Вељка Петровића више од пола века након његове смрти подједнако вреднују његова дела и нарочито истичу стваралачко опредељење овог писца да књижевним радом „држи до обичаја својих предака” (Поповић, 2009: 178) и да слика „крилату грудву земље”7. Тематску кохерентност овог опуса истицао је и сам писац: „моје новеле третирају махом проблеме националне психологије и борбу раса у некадашњој Јужној Угарској” (нав. према: Поповић, 2009: 63). И као репортер часописа Браник Петровић је подједнако био заокупљен „малим” човеком, а истинским јунаком, те описи градова у његовим репортажама почињу портретом: „Сељаци и сељанке у дивно везеним прегачама, слободно се крећући као до сад никад, машу, смеју се на наш воз и бришу сузе.

\footnotetext{
${ }^{7}$ Наслов књиге песама Вељка Петровића (Нови Сад: Матица српска 1965).
} 
Особито се сви згрћу око генијалног стратега г. генерала Радомира Путника, поздрављајући га као спасиоца. А он се скромно и очински смеши, без труни утегнутости на коју смо свикли.” (Поповић, 2009: 43) Читајући критичка запажања Младена Лесковца (1968: 7) „Пред делом Вељка Петровића” да „у прози овог писца моћно пулсира (М. Лесковац: пулзира, прим. аут.) живот нашег села и града последњег полустолећа, (и онај њихова здравља, и онај њихових хладних болести)”, те да Вељкови приповедачи „тачно опсервирају" детаље тог живота и нијансе његовог пулса, скалу његових мириса, да анализирају, тумаче, и у палимпсесту стварности откривају атавистичко, ирационално, вечно, полако освешћујемо да у једном кутку савремене прозе са нашег поднебља можемо наћи „кришку сунца” Петровићевог дела. „Кришка сунца” у делима Вељка Петровића је и метафора огранка једног национа који се, некада на туђем тлу, а каткад и у туђем свету бори за свој опстанак (др Стипа Паштровић у приповеци Буњ $а$; Бабијан Липоженчић из приповетке Салашар). Иво Мунћан, аутор романа Суние на кришке, и сам је „кришка сунца” једног национа. Наслов овог романа (Суние на кришке, 2014) алудира на стих Петровићеве песме Кад сељак умире: „Сунце скоро зашло, још остаде кришка".

Петровића и Мунћана спајају „крваво живе теме” и идејно тежиште дела. Они описују и приказују своју земљу - родну груду и идеју човекове борбе за њу и са њом, негују култ села и патријархалних вредности, проблматизују појам однарођавања. Човек је као земља; тачније, човек је земља у Петровићевом и Мунћановом делу. Земља је „гнојна, здрава, јака / каснога цветања а мразева прерани" (Петровићева песма Српска земља, 1906). Међу прозним делима Иве Мунћана, чари домаје и препознавање коренског у нама на најбољи начин дочарава збирка кратке прозе $У$ вртлогу времена (2013), а то је резултат дубоке спознаје до које долазе њени јунаци тек у додиру са својом равницом - благом, неизмерном, гнојном, јаком. Укорењен у равничарску земљу Петровићев и Мунћанов лирски субјекат, али и јунаци њихових приповедака, исказују амбивалентна осећања („,о, ја те мрзим, јер нико ко ја / не љуби тако, моја мати драга!” (Српска земља)). Амбивалентна осећања пандан су грчу душе под талогом (у талогу) земље натопљене (односно „отроване”) крви.

Иво Мунћан је тему вечитог сукоба између својег и туђег, између овде и тамо, те исконску жудњу за својим комадом земље и Сунца обрадио у форми кратке приче. Јунаку збирке $У$ вртлогу времена није стран ни доживљај своје земље као стране, хладне, туђе. Оваква осећања где год да (,,рекло би се, из навике" (37)) крене, са собом носи Сима, средишњи лик приче „Четири чаше на столу”. Сима је типски лик и метонимија је оних сељака који су остали у својој равници да са њеног тла сведоче о променама које су је задесиле. Три чаше вина које Сима наручује у кафани сваког четвртог у месецу намењене се онима којих више нема, његовим пријатељима. Иако је 
остао на плодној равници, под „кришком” свог Сунца, овај „последњи Антеј” не напаја се снагом са свог родног тла, већ „дубоко загледан у себе тражи још неке кутке снаге неопходне да се вине даље...” (37). Вешто бирани детаљи попут зрака сунца, бора на челу, шуштања кукуруза, хрскаве корице врућег хлеба и др. семантички корелирају и упућују на комад (,кришку”) своје земљи, као средишњем мотиву Мунћанових прича. Ликове његових прича покреће земља, тачније жеља да поседују још један педаљ, ма ,десет ланаца” те плодне равнице. Њихове њиве су бремените: „Па смо на њиве грабили такорећи између два облака и две кише.” (22), рећи ће свако од њих.

Док лик старине у делима Иве Мунћана, попут ратара и салашара у делима Вељка Петровића „челом тражи са грана одбегло лишће / ћути и левим оком подупире снопове које случајно олуја прети да разнесе / а десно око забада под кошуљу видика..." (Старина у башти), сам неодољиво подсећа на белог деду Вељка Петровића којег овај писац у истоименој причи описује како „бауља међу бундевиним врежама”, док се за њим шуња унук Вељко, „мала малоћа”. Башта је цео свет и у Мунћановој краткој прози! Шум травке у овом свету нешто је велико, силно, моћно! Своје приче из живота Мунћан мотивише сусретом свога (усамљеног) приповедача са природом - јутарњим Сунчевим зрацима, додиром са листом шљиве или јабуке. Овај сусрет има карактер Догађаја, док се одлазак у башту или на њиву може назвати правом светковином.

Вељкова песма земљи, родној груди је црвена (Црвена песма, 1906); израста са тла - талога труле крви и праћена је тутњавом мегдана. Песничка слика црвене, „тутњаве” песме која се у руменој светлости уздиже са тла оваплоћење је буктања, врења у песничком субјекту - смеоном, дрском, плахом. У песми Кенигрец Петровић пева о „врелој, лудој, лудој српској крви” и поносном, дивном, немирном и „гордом роду”, док узроке овога налази у атавистичком, али и у самој земљи из које су поникли несмирници. Већина Петровићевих песама из прве деценије 20. века (Под ћивотом кнеза Лазаpa, Повратак, Србији) инспирисана је одређеним историјским околностима (1908. је мађарска влада експроприсала угљени мајдан до манастира Раванице, где су се чувале кости кнеза Лазара и сву околину населила Мађарима, а исте године је издата и наредба од стране поменуте владе да се Срби морају одрећи своје ,заветне мисли” и идеје националног уједињења како не би били протерани; у овом периоду Срби су били изложени и другим притисцима мађарске владе), али се свака дотиче универзалног у нашем националном бићу. У песми У родитељској постељи, 1909, песнички субјекат свој доживљај родне груде уздиже до епских размера; као да у име колектива сведочи да ,jедно је срце у нама”. За поетику Вељка Петровића јако је важно што појам песника дефинише баш у родољубивим песмама: „слушај велико срце / народа, светова! [...] ко висок, изнад горе, бор". Песник треба да пева из срца свог народа, у име свог народа, са проницљивошћу оног који 
„на брду ак и мало стоји”; Петровићев песник (Песнику) је хиперсензитивних чула и нерава, али у позитивном смислу; он чује било срца земље, шум удаљених житних поља, трептаје душе свих нас. Његова је „песма” земљи и човеку спевана.

Укорењен и окупан снопом зрака свога Сунца, јунак збирке У вртлогу времена Иве Мунћана уздиже се изнад једнократности и пролазности, а његова лична судбина постаје судбина једног национа. Истински је живот једино „у знаку аманета [овог, свог] простора и видика.” (103), закључује приповедач приче „Мајка”, само једне у низу уплетене песме у прози. Она (Земља-Мајка) је срце света. Попут „ћутљиве статуе” (103), „скамењене лавице” (104) Банатска, равничарска земља „стајала је као стена док се мимо ње све ковитлало, превирало, плакало, туговало” (106). Горела је, тресла ce, али, одмотавањем клупка времена, њено „стабло” је расло. На сличан начин, деценијама пре Мунћана, Вељко Петровић пише о Војводини као горштакињи гордој (Војводино стара, зар ти немаш стида).

Песнички субјекат Петровићевих песама сваким поступком, уздахом, линијом свога лица исказује љубав према земљи која га је надојила. Ратар из истоимене песме је сам песник који се стапа са објектом опсервације управо у тренуцима ослушкивања „семена које нечујно пуцкета” и усклика истинске (исконске) радости која се може осетити само међу богатим браздама, у мору жита. Ту сељак чује како ,земља збори”. Шуштање зрелог жита и усклик радости утичу у тиху, несвесну, а снажну песму. У Петровићевој песми Чобанов бадюак главни мотив је такође песма. Она је „тиха, наслеђена, проста", поје се с дршћућим гласом. Усамљени чобан(ин) песмом захваљује земљи што се сам не осећа усамљеним. Музика земље и равничарског ветра ремете тишину (усамљеност) чобанина на највећи хришћански празник. Песма земљи и песма земље је ,љубав првобитна”, вечна, не да се притајити ни под коровом времена. Песма греје, плави. Петровићево родољубље у овој песми нема ритам ратне корачнице, нити је израз предратних и ратних афирмативних фраза; напротив, оно је конкретизовано са емоционалног аспекта (кроз доживљај земље); уједно, оно је и надахнуће. У том полету радости међ' шуштавим житом, ратар се сав растаче у песму. Вељко Петровић пева о „човечјој земљи”, земљи великог срца које бије кроз нас; о земљи - крилу која булкама тапше, липама хлади. Последњи доживљај сељака који умире (Кад сељак умире) јесте топлина благе, неизмерне равнице и кришке равничарског сунца која силно греје. Сељак равничар умире топлом тугом, благом, смерном која тек задрхтава њиме. „Ни душа му није отишла далеко." (Кад сељак умире) Јунаци збирке У вртлогу времена Иве Мунћана чезну за кришком идиле јер је у вртложном времену у којем живе она више него довољна за срећу. У времену када је све „на кришке”, оно мало Сунца и земље довољни су да приме цео свет. Живећи у вртложном времену, а „мимо света”, Мунћанови јунаци као највећу вредност истичу топлину 
родне груде. „Такву топлину - убеђен си - ниси више никад доживљавао. А била је то некаква слатка топлина, која не да ти се завлачила у кости, него те обливала одозго, од главе почев и силазила, спуштала се низ рамена, залазила под пазухе, клизила по трбуху...” $(97,98)$

\section{5. Закључак}

Комплексној теми и обимном поетском, приповедачком, публицистичком опусу Вељка Петровића и Иве Мунћана приступили смо кроз анализу поетике усменог приповедања, заступљене у прози поменутих писаца, кроз поступак обликовања њихових књижевних ликова и уочавање њихових сродних карактерних црта и идејних тежишта, те путем анализе мотива родне груде и других антејских мотива којима су заокупљени ови прозаисти и песници. Овако усмерено и путем ових тема организовано истраживање осветлело је још важних смерница за даље истраживање поетичких, формалних и структурних укрштаја двојице писаца заокупљених својом земљом, локалним и националним, а у исти мах општим и вечним. Њихов истинити, реални и живи приказ равнице, равничара, земље, патријархалног и националног, те човекове разапетости између свог и туђег, потврђује један континуитет у поетици Вељка Петровића, након Вељка Петровића. Два ствараоца, Вељко Петровић и Иво Мунћан, не само да су рођени под једном звез$\partial о м^{8}$, већ су ту исту звезду тежили досећи. Стићи и престићи Петровићеве уметничке домете није нимало лако, али док год има писаца који се хватају у коштац са овим изазовом „грлица” Вељка Петровића и даље ће живо певати тииим гласом човека дубоко укорењеног у своју земљу.

\section{Извори}

Мунћан, 1977: И. Мунћан, Бесана ноћ, Букурешт: Издавачко предузеће Критерион, 1977.

Мунћан, 2013: И. Мунћан, У вртлогу времена (кратка проза), Темишвар: Савез Срба у Румунији, 2013.

Мунћан, 2014: И. Мунћан, Сунце на кришке, Нови Сад: Православна реч, 2014.

Петровић, 1068: В. Петровић, Приповетке, Београд: Просвета.

Петровић, 1969: В. Петровић, Песме; Есеји. Нови Сад - Београд: Матица српска $-\mathrm{CK} 3$.

\footnotetext{
${ }^{8}$ Под једном звездом наслов је књиге чији је приређивач и коаутор Иво Мунћан. Књига је, заправо, омаж писцу Михају Еминескуу (1850-1889) чији опус покрива широк спектар тема, од природе до друштва. Осмислили су је, и приредили Иво Мунћан и Душан Милићев. У оквиру ње су штампали и своје две песме.
} 


\section{Литература}

Бојанић Ћирковић, 2018: М. Бојанић Ћирковић, „Антејски мотиви збирке $У$ вртлогу времена Иве Мунћана", Исходишта, год. 4, бр. 4, Темишвар - Ниш: Западни универзитет у Темишвару, Савез Срба у Румунији - Филозофски факултет Универзитета у Нишу стр. 49-60.

Бојанић Ћирковић, 2019: „Жанровска преплитања у делу Сунще на кришке Иве Мунћана", Исходишта, год. 5, бр. 5, Темишвар - Ниш: Западни универзитет у Темишвару, Савез Срба у Румунији - Филозофски факултет Универзитета у Нишу, стр. 57-67.

Вукадиновић, 1992: М. Вукадиновић, Рекли су о прози Иве Мунћана, у: И. Мунћан, У вртлогу времена. Темишвар: Савез Срба у Румунији [2013], 158.

Гордић, 2000: С. Гордић, Огледи о Вељку Петровићу, Београд: Завод за убенике и наставна средства.

Гргурић, 2009: И. Гргурић, Вељко Петровић (1884-1967): каталог изложбе, Нови Сад: Библиотека Матице српске.

Иванић, 2015: Д. Иванић, „Прича из живота: ка одређењу једне прозне врсте”, Ниш: Philologia Mediana, год. 7, бр. 7, стр. 15-23.

Јерковић, 2014 (ур.): В. Јерковић, Равница Вељка Петровића / Книжевни портрер Милисава Савића, зборник саопштења, Сомбор: „Вељкови дани” - Градска библиотека „Карло Бијелицки”.

Клисурац, 1973: Ч. Ч. Клисурац, Рекли су о прози Иве Мунћана, у: И. Мунћан, У вртлогу времена. Темишвар: Савез Срба у Румунији [2013], 156.

Лесковац, 1968: М. Лессковац, „Пред делом Вељка Петровића”, предговор у: В. Петровић, Приповетке, Београд: Просвета, стр. 5-15.

Милин, 1977: Ж. Милин, Рекли су о прози Иве Мунћана, у: И. Мунћан, У вртлогу времена. Темишвар: Савез Срба у Румунији [2013], 156.

Милин, 1999: Ж. Милин, Одабрани осврти. Темишвар: Миртон.

Палавестра, 1963: П. Палавестра, „Токови традиције - српска и хрватска поезија ХХ века", Савременик : месечни часопис. год. 9,књ. 18, бр. 8/9 (август-септембар 1963), стр. 101-119

Петровић, 2014: Т. Петровић, „Равница Вељка Петровића”, у: В. Јерковић, Равниияа Вељка Петровића / Книжевни портрер Милисава Савића, зборник саопштења, Сомбор: „Вељкови дани” - Градска библиотека „Карло Бијелицки”, стр. 7-20.

Поповић, 1973: Н. Поповић, Рекли су о прози Иве Мунћана, у: И. Мунћан, У вртлогу времена. Темишвар: Савез Срба у Румунији [2013], 155.

Поповић, 2009: Р. Поповић, Воћка на друму, Београд: Службени гласник.

Секулић, 1924: И. Секулић,

Скерлић, 1971: Ј. Скерлић, Критике. Нови Сад - Београд: Матица српска - СКЗ. 
Mirjana Bojanić Ćirković

\section{IVO MUNCAN AND VELJKO PETROVIC IN COMPARATIVE INTERPRETATION}

\section{Summary}

In this paper we analyze the poetics of two writers, Ivo Muncan and Veljko Petrovic, through a comparative approach to their stories and poems. We investigate the themes and motives interweaving of two poetics aimed at the problem of national identity and the identity of the individual in contact with a modern times. Special attention will be devoted to finding similarities in meaning motives of the country, villages, tradition.

Key words: Ivo Munćan, Veljko Petrović, Antean motives, national identity, village, tradition, oral storytelling. 